\title{
Price-Disequilibrium Model of the International Financial Grid: Innovation, Crisis, and Off-Shore Banking
}

\author{
Frederick Betz ${ }^{1}$ \\ ${ }^{1}$ SUNY Korea and Portland State University \\ Correspondence: Frederick Betz, SUNY Korea and Portland State University. E-mail: fbetz@venture2reality.com \\ Received: April 16, 2015 \\ Accepted: September 1, 2015 \\ Online Published: September 8, 2015 \\ doi:10.5430/bmr.v4n3p43 \\ URL: http://dx.doi.org/10.5430/bmr.v4n3p43
}

\begin{abstract}
International cash flows are involved in the process of international banking; and the modern technologies of information and communications (IC) have increased the speed, volume, and complexity of international flows. But at the end of the twentieth century, the global world began to experience destabilizing international flows -particularly in the Asian financial crisis of 1997, Global financial crisis of 2007, and Euro crisis of 2010. In using the IC technologies, how has international banking increased the frequency and intensity of international financial crises? Did the IC technology somehow encourage the failure of international financial institutions in performing with basic financial 'integrity', 'honesty', and 'prudence'? To answer these issues, one must observe the financial system within an IC network, a kind of financial 'grid'. We use the concept of a 'financial grid' and model the grid as a network of institutional intermediaries, matching financial supply-to-demand. To construct this topological model, we review the recent history of investment banking and of the organization of off-shore banking into an unregulated but centralized international financial grid.
\end{abstract}

Keywords: Financial Crises, Financial Networks, Macro-economic Models

\section{Introduction}

Most of the literature on international capital flows have focused upon the issue of -- whether capital should be allowed to flow freely into and out of the country or should the country try to control the flow? Barry Eichengreen wrote: "The implications of capital mobility for growth and stability is one of the most contentious and least understood issues of our day. The controversy is long standing; one only need recall Nurskse's emphasis on destabilizing capital flows in the 1920s or Keynes's and Whites' effort to construct an international regime with limits on capital mobility following World War II. But the depth of disagreement in both academic and policy circles was pointed up by the Asian crisis (in 1998). This event which followed on the heels of widespread capital liberalization in the first half of the 1990s, convinced many observers that early opening to international capital markets is a recipe for disaster. But it also led others to the opposite conclusion." (Eichengreen, 2004)

Underlying this disagreement on capital liberalization (about its liability or benefit to economic growth) has, however, been a common assumption - that the 'structure' of the banking institutions controlling capital flow has remained unchanged over the twentieth century. And this empirically was not true. The introduction of information and communications (IC) technologies (e.g. computers and electronic networks) into the financial sector has changed financial transactions (process and products). In the course of the last years of that century, IC technologies have electronically developed banking networks into a kind of financial grid.

The investigative financial reporter Suzanne Mcgee used the term 'financial grid' to describe the U.S. Wall Street institutional infrastructure as an 'abstraction'. A 2009 meeting of a U.S. Senate Banking Committee was trying to understand the financial collapse of Wall Street in 2008. One senator asked the question: "Does Wall Street owe the American people an apology?" The question was asked of the then Chair of the Federal Reserve System, Ben Bernanke. Susan Mcgee reported his response: "He tried to describe to the committee the concept of 'Wall Street'. After a lot of hemming and hawing, Ben Bernanke finally replied that ... 'Wall Street' is a . . is a . . . is an abstraction." (Mcgee, 2010)

The abstraction to which Bernanke was referring is that of a 'system' - not a place nor buildings nor a business but a process of functional transactions - a financial system. The abstraction is about how institutions in the financial system provide services. But Wall Street is a private system, and to understand why the public needed to 'bail-out' a 
private system, Suzanne McGee used the analogy of an electrical power system to a financial system. Mcgee wrote: "Wall Street, in its totality, involves more than what happens on the floor of the New York Stock Exchange or within the walls of any single investment banking institution. It has become a labyrinth of many different groups and institutions, all of which have one thing in common: they make the whole money grid work more smoothly and more efficiently." (Mcgee, 2010)

An electrical power grid needs to be regulated for the public good, to ensure that power generation and distribution companies perform their job of continuously delivering 'power'. In Mcgee's view, so too must the grid of financial systems be regulated to ensure they perform their job of continuously delivering 'money'. Yet in the last half of the twentieth century, there were political moves to deregulate banking in America and Europe. Why was there such an effort to deregulate international banking, even as destabilizations occurred? How had the international banking become 'casino banking' - banks gambling depositors' monies on massive trading and on producing unsound products of high risk and little public good?

One of the unsound products innovated by Wall Street's new 'casino banking' mentality in the beginning of this century was called 'securitization'. It brought down Wall Street in 2008; and in 2009, the U.S. Congress established an inquiry to investigate the crisis. Phil Angelides was appointed Chairman of the U.S. Congress Financial Crisis Inquiry Commission: "I came into my position as chairman of the commission with what I thought was a reasonable understanding of the American financial system, and I had this quaint notion that it was a system designed to allocate capital to the economy for the purposes of creating jobs in enterprise and long-term sustained wealth for our society. I must tell you that over the course of the last year and half, I, along with my fellow commissioners, undertook a journey of revelation. As we did our investigation, we were surprised, we were shocked, we were fascinated and often appalled at what we found. I often felt as if I had entered my local community bank, had opened a door that I wasn't supposed open, and when I opened it, I saw a casino floor as big as New York, New York. And, I may add, that unlike Claude Raines in Casablanca, I was truly shocked at the level of gambling that was going on in Wall Street." (Angelides, 2011)

Wall Street was part of the new international financial grid, which reached down even to local community banks. What kind of international bank regulation is needed to ensure a stable international financial system which allocates capital to economic activity of job creation -- instead of mostly 'gambling'?

\section{Methodology}

The modeling approach in this research is to use mathematical 'topological' models' to show 'structure' (as in a macro-economic model) but connected into 'institutional processes' (as in a micro-economic model). Topological models (planes of connected graphs with processes) provide an effective methodology for a cross-disciplinary approach to structure-function explanations of societal phenomena. The topological model shows both the structure of macro-economic processes and the functional details of institutional processes which control flows in the structure. Applied to economic systems, structure-function modeling (in topological form) enables the description of how macro-economic structures really operate in the empirical reality of institutional economics.

For the empirical input of current institutional economics, we use case studies of the international financial system written mostly by investigative financial reporters. This is a method which historians use to draw upon contemporary writings as sources for historical analysis. We also use extensive quotes from these original case materials to point to the historical documentation about a case. Economic historians also draw upon such sources, which contributes a cross-disciplinary perspective on the reality economic theory and models in historical situations.

\section{Disequilibrium Systems Model of a Financial Grid}

The traditional function of investment banking occurs in what has been called a 'financing life cycle' of business. Investment banking services involves finding investors to finance the start of a business, loaning money to the business to finance its growth, taking the business public by issuing stock, maintaining a trading market in the stock, and assisting the business to issue bonds for operations or acquisitions. Some investment banks (venture capital firms) specialize in financing the 'start-up' stage of a new business; while the traditional Wall Street investment banks specialize in the underwriting the public offering stage. In offering public stock, investment banks had to ensure the continuing market for stock by participating in a stock exchange (e.g. having a seat on the New York Stock Exchange). Traditional investment banks also sold corporate bond issues for further corporate financing.

In a network of banking, Irving Minsky viewed investment and commercial banks as a layered banking system. (Minsky, 1975) Investment banks draw upon commercial banks for leveraged investment loans. The commercial bank takes in deposits of savings, and the investment banks produce financial products to sell to investors and 
commercial banks (demand for investments). An investment bank creates the financial intermediation process by formulating a financial product, which is based upon two economic values: (1) the estimated market value of the capital asset and (2) the interest rate (rent) of the financial product. This financial product is then available for sale in a financial market (e.g. corporate equity stocks in a stock market or derivatives in a derivative market or international currency exchanges in a currency exchange market). The economic value of the financial product is determined by its pricing in its financial market; and if a financial bubble occurs in the market (such as the housing bubble in 2005 in the mortgage derivative market), then the bubble can burst, dropping the market. Thus the financial product value depends upon: (1) its initial value when sold and (2) its later value when traded in a market. The Keynes-Minsky price disequilibrium transaction in a financial market was first modeled in (Betz, 2014); and we show this in Figure 1.

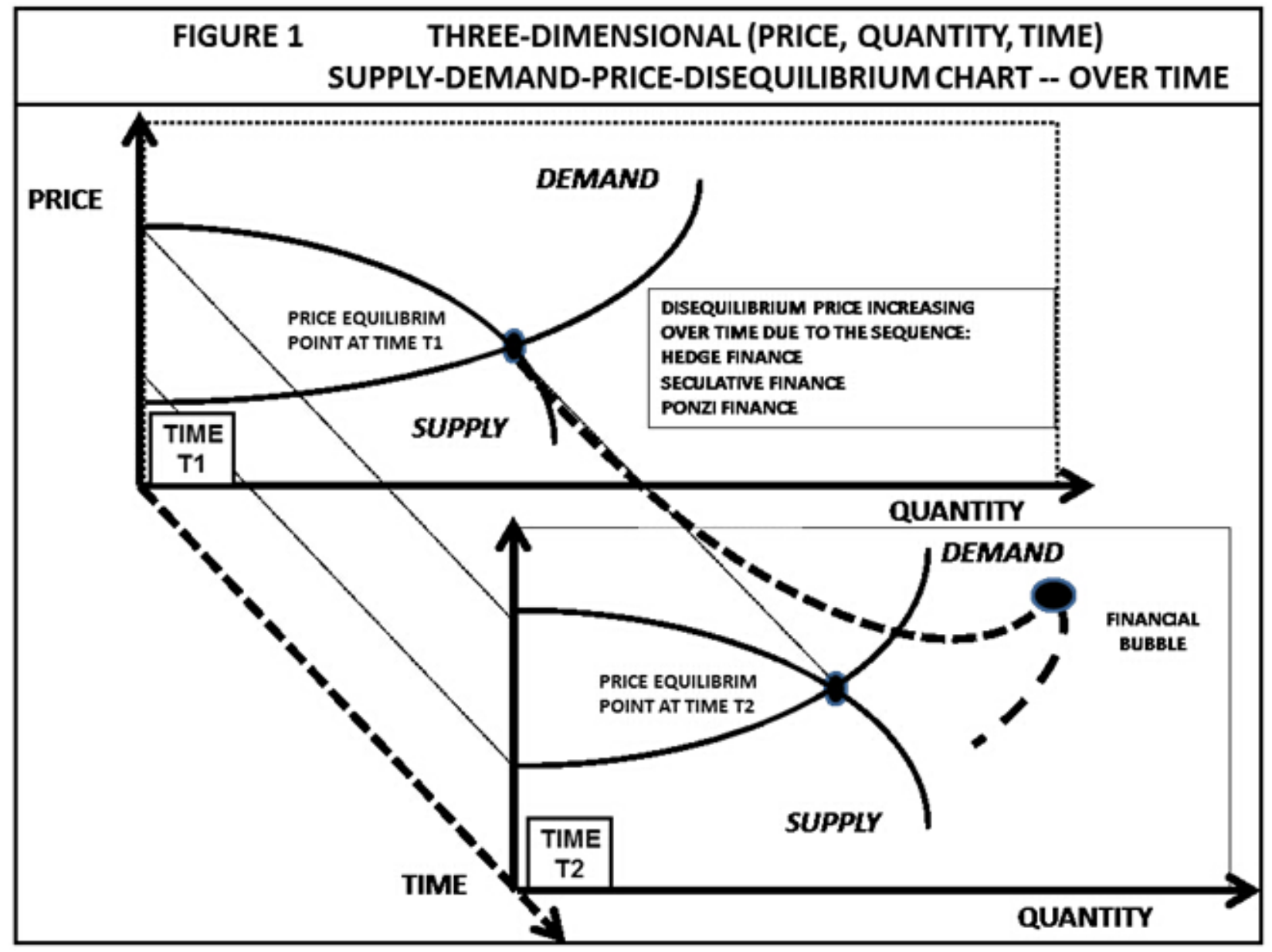

Figure 1. Disequilibrium Price Model of a Financial Market over Time

In a financial market, financial products of capital assets are traded, and a capital asset has two economic values current rent and future liquidity. Over time from $T_{1}$ to $T_{2}$, trading in the market can move from a price-equilibrium point to price disequilibrium, when a market gets hot and traders borrow money to purchase the asset at higher and higher prices. This is possible using greater leverage in the loans the trader gets to trade in the market. Debt makes a financial process operate. Yet one aspect of debt can destabilize the process; and this is 'leverage'. To increase profit, a financial system uses debt to finance the purchase of capital assets. Profits can be increased through financial leverage; and this is the financial rational of 'leverage' (more 'present-debt' toward greater 'future-wealth'). However, when present-debt is too large (too highly leveraged), it might not create future-wealth but, instead, bankruptcy.

Excessive 'leverage' increases the likelihood of bankruptcy and not future-wealth. This was earlier pointed out by Irving Fisher, who called a financial state of excessive-leverage as 'debt deflation.' (Fisher, 1933) Later Hyman Minsky called a state of excessive financial leverage as 'Ponzi finance'. (Minsky, 1975) Even later, Paul McCulley continued to emphasize the importance of the economic role of 'leverage': "At its core, capitalism is all about risk taking. One form of risk taking is leverage. Indeed, without leverage, capitalism could not prosper. . And it is grand, 
while the ever-larger application of leverage puts upward pressure on asset prices. There is nothing like a bull market to make geniuses out of levered dunces. . . . (Speculation) begets ever riskier debt arrangements, until they have produced a bubble in asset prices. Then the bubble bursts ..." (McCulley, 2007)

Figure 1 shows the impact of leverage on a price equilibrium model (by modifying the 2-dimentional 'price-equilibrium chart' with the addition of a 3rd-dimension of time). This graph shows a supply-demand curve at two different times, T1 and later T2. In the time-dimension, one can see how a 'price-disequilibrium' situation can arise over time, as a 'financial bubble'.

Next we provide a system dynamics model of how financial products are produced by an investment bank, which are then traded in a financial market (with a tendency to price disequilibrium). As shown in Figure 2, the investment bank process can be depicted in systems notation, with a 'disequilibrium financial market model' in the middle of the system - with a demand side and a supply side. The financial market is composed of financial products created by investment banks - products which match capital supply (demand side) to capital need (supply side). The investment bank creating financial products for a financial market is the center of the systems model. To the right side (supply side) of the systems model are sellers of capital assets, and to the left side are buyers of capital assets (demand side). The investment banks are the banking intermediary which create the financial products which sell capital assets to buyers.

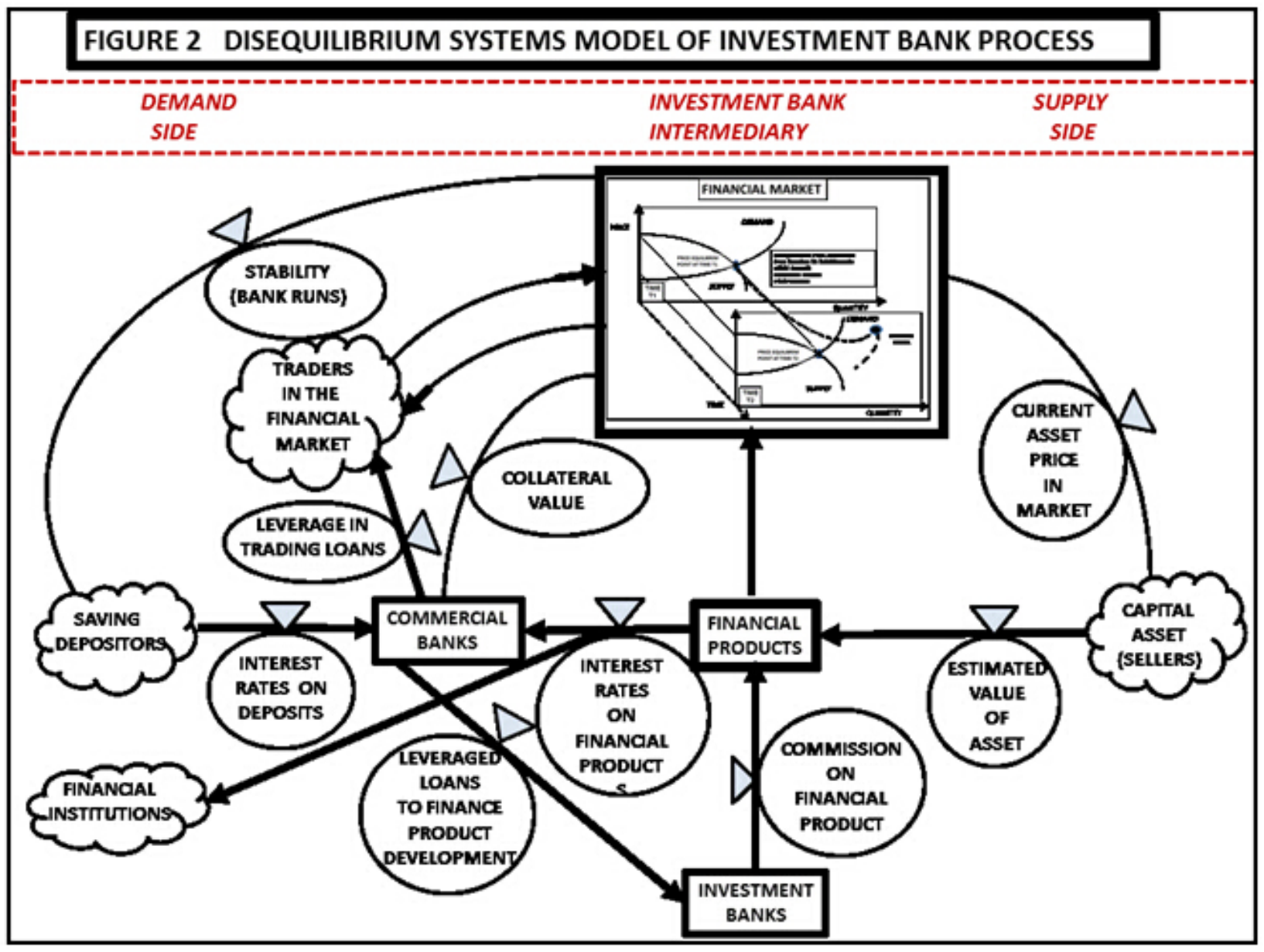

In systems notation, the 'cloud' symbols are 'sources' as origins of things entering the 'flow' of the system -- things which flow along the 'arrow' lines of the system. The 'rectangle' symbols are stocks of things which receive, send, or hold the things flowing along the arrows. The 'circle-with-triangle' symbols are 'control valves' which control the 'rate-of-flow' of things along the arrows of the system. The 'system' model of an institutional process indicates a flow of things between sources and stocks in the system, controlled by valves along the flow lines.

In the case of a systems model of investment bank procedures, there are two sources: a source of savings (buyers) and a source of assets (sellers). The flow is 'capital' from a source of savers to a source of asset sellers, through the intermediary of the creation and trading of 'financial products' - products created by investment banks and traded in 
a financial market. The 'price-disequilibrium' aspect of the investment process model is in the financial market -which over time might go into a financial bubble (due to trader speculation in the market) and then a Minsky moment occurs when the financial bubble collapses.

As a financial intermediary, an investment bank brings together a financial supply side of capital assets to trade in a market with a financial demand side of buyers of the assets. For example, when an investment backs assists a private company in making a public offering of stock, the private company sells equity assets as stock and purchasers of the stock buy equity in the company.

The source in the supply side for the financial products are sellers of capital assets. The value of the financial product is controlled by a rate of the estimated-value-of-the-asset compared to the current-asset- price trading in the financial market. In financing the creation of a financial product, investment banks often get loans from commercial banks; and there is leverage in the product-development loans. (For example in a 2007 case of securitized mortgage bonds, an investment bank's hedge fund within Bear Sterns borrowed $100 \%$ of the cost of the mortgage they purchased for securitization for one year from the commercial Bank of America - even when the mortgage wouldn't pay back principle for thirty years.)

To model the demand side of financial products, the source of savings are individuals who make deposits in commercial banks, and the commercial banks purchase financial products. Also other financial institutions (mutual funds, hedge funds, pension funds, insurance companies) purchase financial products. The interest rate on the financial product is the controlling rate for its purchase by commercial banks and financial institutions. Commercial banks also make leveraged loans to traders in the financial market; and the trader's purchase of financial products is then held as collateral by the banks. Commercial banks use interest from a financial product to pay interest to their savings depositors.

Thus the stability of the commercial banks can then depend (1) upon the quantity of financial product purchased by the bank and (2) upon the value of the collateral held on loans to traders. If the financial market collapses, then commercial banks are saddled with valueless financial products and the bad loans of the traders. The banks can become insolvent. (For example, in the New York stock market collapse of 1929, stocks held as collateral in banks which made loans to traders purchasing stocks-on-margin became valueless; and many of these banks went bust, through 1930, 1931, 1932. In the derivatives market crash of 2007, some large U.S. banks, holding mortgage bonds as collateral, collapsed. Others would have collapsed, without the U.S. government bail-out.)

Thus the disequilibrium model of a financial market is composed of the financial products which trade capital assets; and the financial market may move toward a price disequilibrium, if and when the market becomes hot, as traders bid the price of the financial product higher into a financial bubble. As traders bid higher prices in the market, they need increasing larger leverage in the loans for purchase. When the leverage in the loans gets too high, then the market grows into a financial bubble and can collapse. In a financial market collapse, the financial products which the commercial banks have held as collateral can become valueless (toxic assets). The banks can become insolvent and collapse (bank runs).

This models the 'abstraction of Wall Street' in terms of a price-disequilibrium systems model of a financial market -created in the process of connecting the supply side (sellers) to the demand side (buyers), with investment banks acting as financial intermediaries. Suzanne Mcgee wrote: "All of the players (on Wall Street) perform functions that link the 'buy side,' those who have capital and want to invest it profitably, and the 'sell side,' those entities in need of capital. 'At its heart, when it is doing what it does best, Wall Street is a superb gatekeeper, making matches between investors and businesses, governments, or anyone else who needs to finance something,' explains Mike Heffernan, a former Morgan Stanley banker.” (Mcgee, 2010)

The sellers and buyers of financial products have different interests, which the investment bank must bridge in creating a financial product. Suzanne Mcgee wrote: "The sell side wants to get as much capital on the most favorable terms possible from the buy side - investors who range in size and importance from individuals to mutual fund conglomerates such as Fidelity, and include hedge funds, private equity funds, foundations, college endowments, pension funds, venture capital partnerships, and ultra-wealthy individual investors such as Microsoft cofounder Paul Allen or financier George Soros. In a perfect world, the sell side would love free money - with no interest payable, no specific term for repayment, and no promises about increasing the value of the investment. It is the myriad institutions that collectively make up Wall Street that (in exchange for a fee) bring together the two parties and negotiate a compromise: the terms on which the buy side is willing to invest some of its capital and the sell side is willing to agree to in order to get its hands on that capital. Banks have been fulfilling that kind of function in more limited ways for centuries.... Wall Street exists to help investors and those in need of capital find their way through 
the financing maze. Investment bankers still not only link the two sides but also help them sort out what terms are fair for the kind of capital being sought." (Mcgee, 2012)

In the twenty-first century, how did it happen that 'Wall Street' investment banking in the U.S. moved away from this traditional economic role toward 'casino banking'? Casino banking gambles high-risk financial products of questionable quality, little public good, and prone to market bubbles. Why did Wall Street take this path?

\section{History -- Wall Street 'Mayday'}

Historically, Wall Street investment banks had collected fixed fees for buying or selling of stock by investors on the stock exchange. While corporate start-ups, IPOs, and bonds were occasional events, earning commissions for the investment banks, the continuous trading of stocks provided a steady stream of income for the investment banks. But a large stream of steady profits from stock trading came to a sudden end for Wall Street investment banks. Suzanne Mcgee wrote: "May 1, 1975, has gone down in the history of the Street as "Mayday," the date the Securities and Exchange Commission had dictated would mark the end of fixed trading commissions in the stock market. Overnight, Wall Street's comfortable existence was shaken; its long-standing business model was turned upside down." (Mcgee, 2012)

Trading stock on the New York Stock Exchange cost a fixed fee (dependent upon the dollar value of the trade). This generated a steady and large income stream for the investment banks. Mcgee quoted Fred Joseph, former CEO of Drexel Burnham: "I was a big producer, because I'd do one trade in connection with a deal. I could make a $\$ 500,000$ fee without discussing it with the client. This was due to the fee being fixed and institutional investors making large and frequent trades." (Mcgee, 2012)

Fixed commissions on executing stock trades provided a secure and continuous base of revenue for U.S. investment banks. The commissions produced large profits which financed overhead activities such as 'investment research' by the Wall Street banks. When the fixed commission structure was deconstructed, investment banks had to turn to intermittent and non-recurrent business activities to generate large commissions. Suzanne Mcgee quoted Wilbur Ross about the change: "Wall Street's Mayday changed the whole nature of Wall Street; what we did and who we were. Research suddenly had no value in its own right and wasn't being subsidized. So the clever people on the Street said, 'Okay, we'll use these smart and well-paid people to bring in investment banking business.'” (Mcgee, 2010)

With this change in revenue flow, Wall Street could not afford to protect the investor with financial research or even financial due diligence. This was the beginning of the evolution of Wall Street investment banks from acting as proper financial intermediaries to casino banking - trading, pumping, and dumping. Suzanne Mcgee wrote: "The ugly end to the U.S. dot-com boom in early 2000 drove that message home to Wall Street decision makers like nothing else had done. They had spent the waning years of the twentieth century chasing the kind of fees that had been the bread and butter of Wall Street: taking start-up technology companies public, raising both debt and equity for the likes of WorldCom and AT\& T Wireless, and pocketing merger advisory fees by helping companies such as Cisco and JDS Uniphase snap up innovative young companies. ... But that happiness could endure only as long as the market bubble kept inflating. ... The fact was that Wall Street firms no longer needed to rely purely on the fees they earned for overseeing processes such as underwriting, sales and trading, or advising on mergers. These intermediary functions were profitable only when they could be done in tremendous volumes, as had happened at the height of the dot-com boom. The longer the slump that began in 2000 lasted, the more Wall Street needed to find an alternative source of revenue, preferably one with a higher profit margin." (Mcgee, 2010)

\section{Institutional Change in Wall Street}

After 1973, the history of Wall Street can then be recounted as a series of disequilibrium bubbles: (1) in the 1970s, there was the Eurobond market, (2) in the 1980s, there were the leveraged buyouts and junk bond financing, (3) in the 1990s, there was the Dot.com bubble and off-book company transactions, (4) in the 2000s, there was securitization and secrecy jurisdictions.

An economic system is implemented as processes operated by institutional procedures. The procedures standardize the economic processes, so that at a given time in a society the system can be described in a steady-state - economic transactions occurring within standardized procedures of an institutional structure. When an event in an economic system alters the institutions and their procedures, then the processes change from a prior steady-stage (stasis) to a different stasis. In societal dynamics theory, one can depict societal change as a sequence of stasis (steady-state) processes, altered by events which change institutional structure in a society. (Betz, 2011) As shown in Figure 3, the 'Mayday' event of 1973 when the US Security Exchange Commission (SEC) ordered that stock trading commissions 
be negotiated; and afterwards, Wall Street financial institutions sought more revenue from 'financial products' rather than trading commissions.

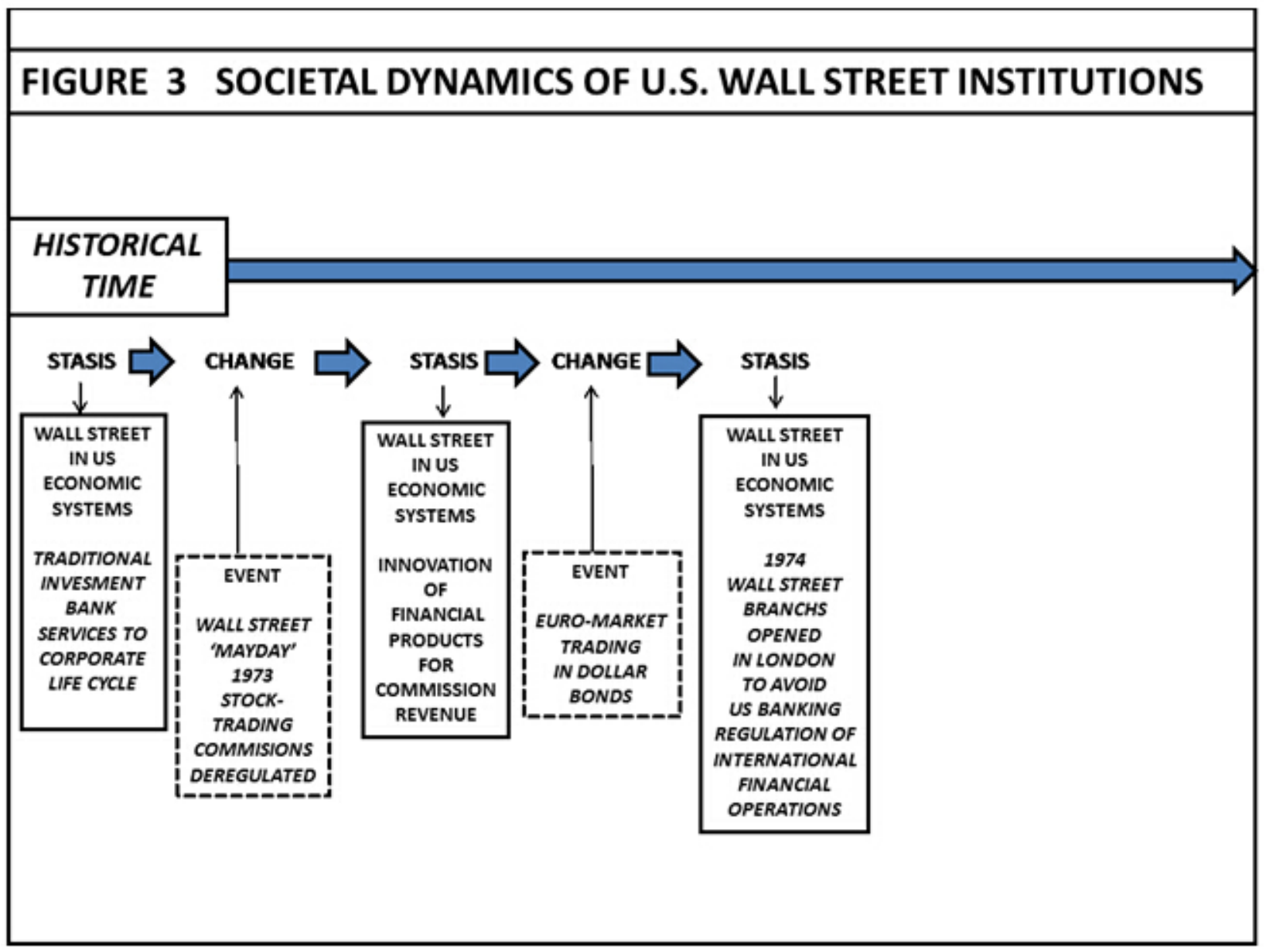

Figure 3. Change Events in Evolution of Wall Street Investment Banking

\section{Wall Street Goes to London - Eurodollar Market}

After 'Mayday', a second 'change' event for Wall Street occurred, when branch offices were opened in London, for avoiding the U.S. bank regulations about international financing operations. Suzanne Mcgee wrote: "Wall Street's fee income from its traditional businesses - buying and selling stock on behalf of its clients and underwriting their debt and equity businesses - was threatened. The solution? New products that would address new concerns . . . Globalization also created new market opportunities. In 1971, the United States abandoned the Bretton Woods system of fixed exchange rates, creating a thriving market for options and futures contracts on foreign currencies, such as the British pound, Japanese yen, and Swiss franc. The Eurobond market was another attractive new opportunity. Born in London's financial markets in the 1960s, it involved issuing dollar-denominated debt outside the United States, meaning that the issues didn't need to be registered with the SEC and that the companies selling debt didn't need to abide by U.S. accounting rules." (Mcgee, 2010)

The bonds were issued in dollar currency by international companies and sold by bank offices in the City of London. Investors found the bonds acceptable in an international currency, paying good interest and avoiding regulations (banking or taxes) by particular nations. Susanne Mcgee wrote: "The Eurobond market was one of the fastest-growing capital markets around - and, like options, it was a lucrative alternative to plain-vanilla bond deals, rewarding underwriters with higher fees. But trying to build a Eurobond business drove home, yet again, the need for a large and stable base of capital. Not only did trying to grab market share in Eurobonds mean establishing a presence in London, but players such as Morgan Stanley and Goldman Sachs (among the early arrivals) would need to compete with giant commercial banks such as Deutsche Bank and Credit Suisse, institutions that, unlike their U.S. counterparts, faced no domestic rules against using their giant commercial banking balance sheets to help them muscle in and grab investment banking business." (Mcgee, 2010) 
Thus Wall Street's first financial innovation after the Wall Street 'Mayday" was to create and sell Eurobond in the international financial market. This required Wall Street to establish British branches in London, to avoid the U.S. regulatory restrictions on international financial operations by US investment banks.

How did establishing a London branch of a Wall Street investment bank enable the Wall Street bank to escape regulation, national or international? This occurred after the Second World War when the Bank of England decided not to regulate much the British banks (a regulatory 'light touch'). Nicholas Shaxson wrote: "Nobody quite agrees when this new strain of offshore activity first emerged, but it was probably first spotted by a financial regulatory authority in June 1955 when staffers at the Bank of England, the UK's central bank, noticed some odd trades going on at Midland Bank (now part of the globetrotting HSBC). Exchange rates in those days were mostly fixed against the dollar. Banks in London were not supposed to trade in foreign currencies unless it was for financing specific trades for their clients, and they were not allowed to lend against deposits in foreign currencies. Midland Bank was apparently contravening UK exchange controls by taking U.S. dollar deposits that were not related to a specific commercial transaction. And it was also offering interest rates on these dollar deposits that were substantially higher than those permitted by U.S. regulations." (Shaxson, 2015)

The Bank of England had 'looked the other way' (as regulators) in allowing Midland Bank to violate regulations. This opened the lucrative investment bank business in the City of London to take dollar deposits with higher interest rates than offered in the U.S. Dollar deposits followed into the Midland Bank and to other British banks (which also had noticed the implicit 'deregulation'); and the Eurodollar market was born. In Figure 4, we add an international plane to a national plane of the disequilibrium systems model of a commercial-investment bank financial grid.

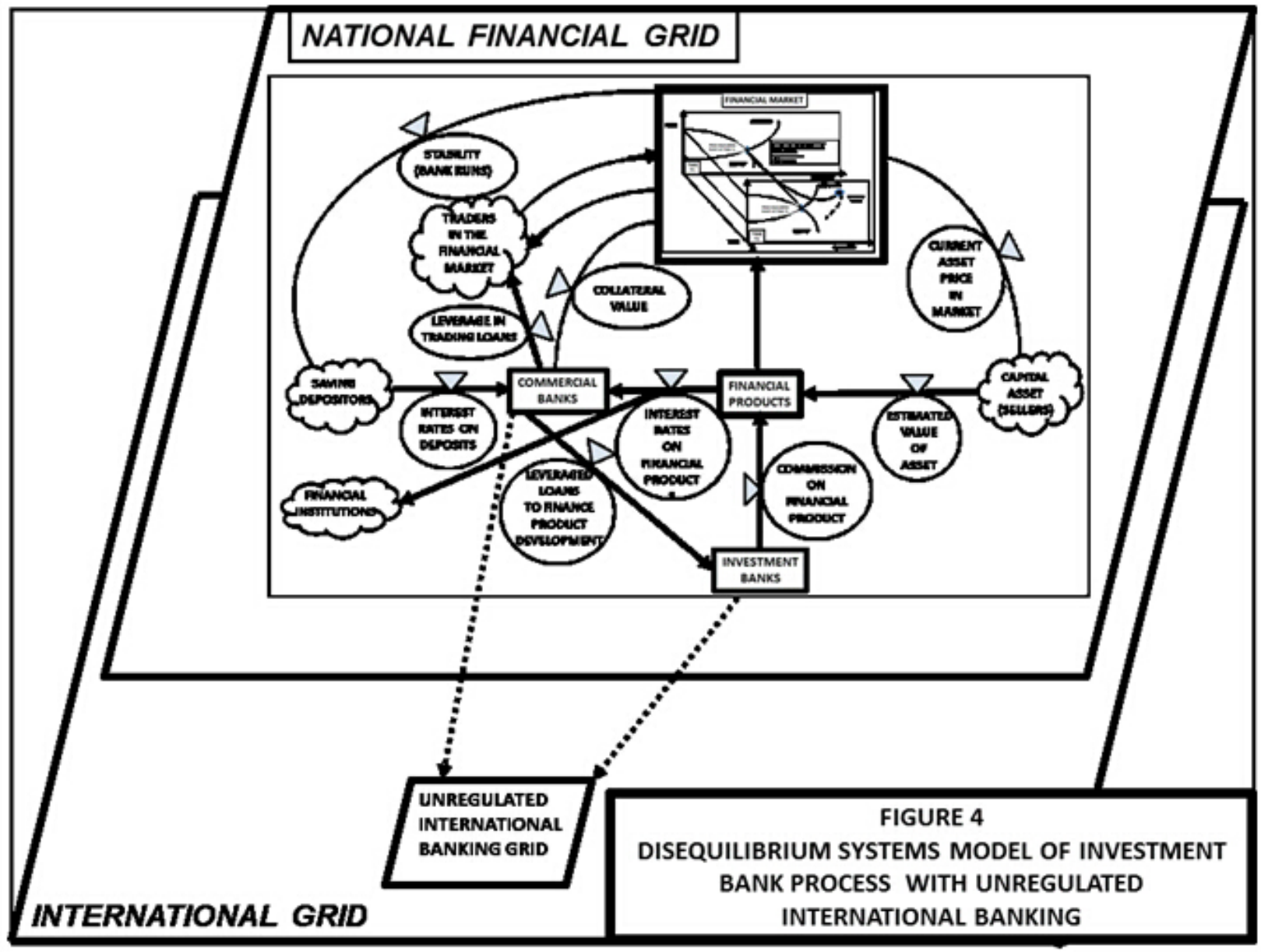

Figure 4. Investment Bank Process with Unregulated International Banking

The commercial or investment banks located in a nation could avoid their nation's bank regulations by opening a bank branch in London. Shaxson wrote: "A Bank of England official called in Midland's chief foreign manager for a chat, to ask why the bank was contravening official controls. Afterward he noted down that the Midland official 'appreciates that a warning light has been shown'. Luckily for Midland, though, Britain was struggling to shore up its 
shaky foreign exchange reserves, and the Bank was reluctant to snuff out a new area of international business. 'We would be wise, I believe, not to press the Midland any further,' the Central Bank concluded." (Shaxson, 2015)

This British practice of 'light regulation' (e.g. only a warning light without any regulatory restriction) by the Bank of England effectively created an unregulated international banking network (financial grid) centered in the City of London. Thus the first step in the evolution of Wall Street banking was to 'go abroad' to London.

\section{Wall Street 'Junk Bonds'}

After the Wall Street 'Mayday' and the opening of London branches, the financial products of Wall Street could expand, periodically innovating new financial products which could be sold at home and abroad. The first financial innovation after 'Mayday' was a new concept of the 'junk bond'. Junk bonds were corporate bonds issued without collateral. There was no capital-asset-value backing the bond (as a loan). The junk bonds were highly risky in that if the bond issuer failed; there was no underlying asset to seize. They were issued and sold for the following purpose. The issuer could use money the bonds raised to buy companies which did have assets; and these purchases were called 'leveraged buy-outs'. The junk bond innovation of Wall Street financed the leveraged buy-outs of ongoing businesses -- but loaded the businesses with debt, reducing the productivity and competitiveness of a 'captive' business - and thereby the competitiveness of the U.S. economy. As indicated in Figure 5, Wall Street went from assisting economic growth in the U.S. economy to stifling growth - trading not in corporate 'productivity' but in corporate 'control'.

\section{FIGURE 5 SOCIETAL DYNAMICS OF U.S. WALL STREET INSTITUTIONS}

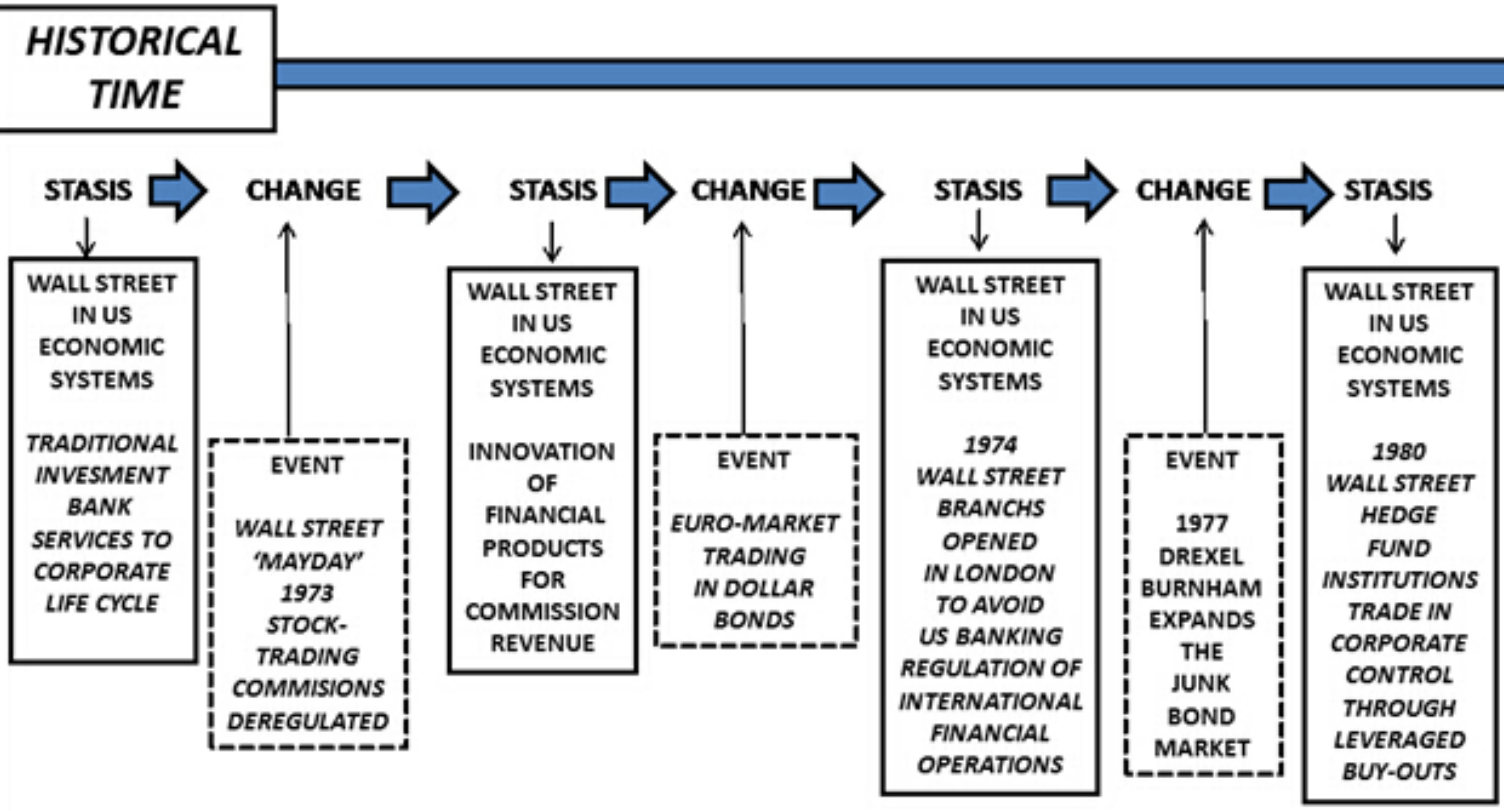

Figure 5. Change Events in the Evolution of Wall Street

Suzanne Mcgee wrote about the 'junk bond' financial innovation: "At a lavish dinner celebrating the fortieth anniversary of Institutional Investor magazine in 2007, Henry Kravis, a cofounder of the giant buyout firm KKR, was one of the evening's honorees - the forty 'Legends of Wall Street.' (That group also included John Gutfreund of Salomon Brothers.) In his speech, Kravis chose to laud Michael Milken, the investment banker who had popularized the "junk bond" during the 1980s. Without Milken, Kravis told the audience, KKR couldn't have done the gargantuan deals that made it famous, and the entire buyout business (which had generated \$ 357 billion in deals in 
the United States alone the previous year, each of which produced massive fees for Wall Street investment banks) would have been stillborn." (Mcgee, 2010)

In 1970, Drexel Firestone was an investment bank focused upon selling bonds and providing stock trading services. Michael Milken began working as a bond salesperson. In 1973, I.W. Burnham purchased the firm and changed its name to Drexel Burnham Lambert. Burnham gave Milken \$2 million to trade in bonds and Milken doubled it in one year. Burnham increased the capital available to Milken to trade and gave him a 35 percent commission on trading profits. Connie Bruck wrote: "The world that Milken created for his faithful . . . would transform the face of corporate America. It would introduce terror and mayhem into countless corporate boardrooms. It would cause frightened managements to focus on short-term gains and elaborate takeover defenses . . . It would cause the loss of jobs, as companies were taken over and broken up. . . In doing all these things, the good and the bad, Milken's machine would stir hatreds and prejudices . . . . Experts would debate whether the value that Milken's onslaught had added to American business outweighed the damage ... . " (Bruck, 1988)

Milken focused on selling and trading bonds without underlying assets, 'junk bonds'. Junk bonds had existed for a long time, as bonds without adequate evidence that the corporation which issued the bond could fulfill its financial contract. What Michael Milken did was to realize that there could be a new market for a new kind of junk bond - a bond without past-value but perhaps future-value. The junk bonds were issued to buy-out existing companies. And for this junk bond market there were new sellers (buy-out artists and hedge-funds) and new buyers (savings \& loan banks, insurance companies, and pension funds). This scheme is modeled in Figure 6.

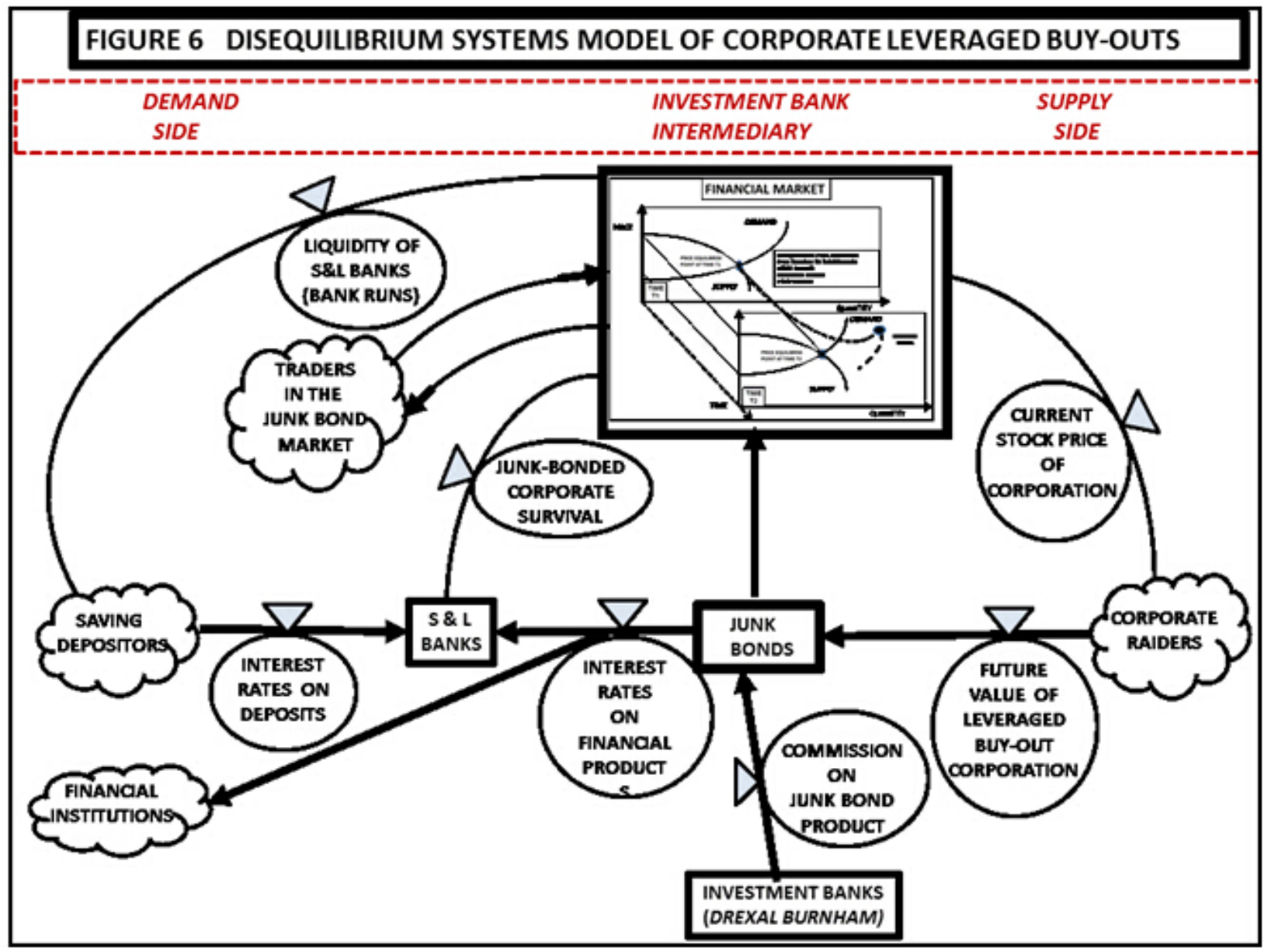

Figure 6. Disequilibrium Systems Model of Corporate Leveraged Buy-Outs

In this disequilibrium model of Drexel's junk bond market, the investment bank of Drexel Burnham led in formulating junk bond offerings for corporate raiders. The Savings \& Loan Bank industry (recently deregulated) eagerly bought the junk bonds because of their high interest rates. Other financial institutions, such as insurance companies, also bought the junk bonds. When the junk bond market collapsed, many of the S\&L banks went bankrupt, as their junk bonds became worthless. 
As Milken at Drexel began to stir the junk bond market, more sellers went to Milken to create junk bonds. They were the 'corporate raiders', people who bought corporate control by buying a corporation's stock, using junk bond financing. With 'junk bond' funding in the 1980s, over a quarter of American corporations were so 'traded' - taken over.

Connie Bruck has listed some of the well-known corporate raiders in the 1980s, who included: Carl Icahn, Victor Posner, Nelson Peltz, Robert M. Bass, T. Boone Pickens, Harold Clark Simmons, Kirk Kerkorian, Sir James Goldsmith, Saul Steinberg and Asher Edelman. (Bruck, 1988) Bruck wrote that: "Michael Milken raised pools of capital for the raiders through Drexel's junk bond offerings. For example, in 1984, Milken sold a $\$ 750$ million blind pool of junk to enable Ronald Perelman to take over Revlon, a leading cosmetics maker. Perelman sold off four of Revlon's divisions to reduce debt and later in 1966, Perelman sold his stock in Revlon through a public offering which made Revlon again a public company." (Bruck, 1988) A captured corporation (such as Revlon), between being 'private' and then flipped again as 'public, had been burdened to handle the enormous junk debt. (Bruck, 1988)

The profitability in the trade derived from transferring the debt liability from the 'trader' to the 'traded corporation'. The 'take-over raider' which issued 'junk bonds' as the raider's liability; but the liability was next transferred by the raider onto the captive corporation. The raider could do this by taking the company private in the 'buy-out'. Then as a private company, the raider could transfer his bond-liability onto the company books, since the company was the raider's private property. In this way, a 'taken-over' captive company' was loaded with the additional debt to pay for its own 'take-over'. This was a private good for the take-over artist but not necessarily a private good for the corporation. The corporate raider 'investor' then had no further liability for the junk bonds previously issued, a nice financial trick.

Kohlberg Kravis, Roberts \& Co (KKR) was a private equity company which pioneered the trading of American corporations through 'leveraged buy-out' financing. It was founded in 1976 by Jerome Kohlberg, Henry Kravis and George Roberts. They had worked together at Bear Sterns, where they started some leveraged buy-outs. Then they left to form their own firm; and proceeded to buy out over 160 companies worth $\$ 400$ billion in private equity transactions.

An example of the heavy burden of debt KKK could put upon a company was its 'captured' First Data Corp. Henny Sender wrote: "Sometime soon (in 2014), KKR hopes to mark its investment in First Data back to 100 cents on the dollar, allowing the private equity group to start preparing a heavily indebted company it took private at the peak of the 2007 buyout boom for an initial public offering ... It has been a long way back for a $\$ 30 \mathrm{bn}$ deal that was one of the largest buyouts ever. At the depths, KKR held the payments processor and information company on its books at 60-70 cents." (Sender, 2014)

As a private company owned by KKK, First Data had been loaded with the junk debt (which KKK transferred from it to First Data). Then First Data was no longer 'profitable', as its revenues after 2007 went only to pay expenses to service interest on junk debt. Thus the value of First Data had declined to 60-70\% of its 'buy-out' price; and in 2014, KKK needed to invest some of its own capital into First Data to make it a competitive company - and to make it show profits, so that KKK could 'flip it' by taking it again public. In 2014, Greg Roumeliotis wrote: "First Data is one of many corporate cleanups quietly underway in the world of private equity, as the industry deals with a debt binge in the years before the 2008 financial crisis." (Roumeliotis, 2014)

The captured corporation had to pay off the junk debt used to capture the corporation; and often could make no investments for the future (such as R\&D and new products). Later (and hopefully) after the captured corporation paid off some of the debt and achieved profits again, the corporation could be taken public again, reaping enormous profits on the investment by the raiders - providing an infinite rate of profit to the raider-trader because they borrowed the money and never held liability for the debt. Some of the stock sales proceeds might be used to pay down some of the debt; but proceeds first went to enrich the corporate raider. Wall Street investment banking went from helping corporations to begin and grow to 'flipping' corporations - a private good with a questionable public good.

But junk bonds had also an impact upon buyers, creating the-first 'bank runs' on the U.S. Savings \& Loan banks (S\&L) in the late 1980s. From 1986 to 1995, one third of the S\&L banks went bankrupt. S\&L banks were chartered to fund home mortgages in the United States, restricted to mortgages with homes as collateral. In 1980 and 1982, the U.S. Congress deregulated the S\&L industry, allowing these banks to invest in anything and many invested in Milken's junk bonds. When Milken went to jail in and the junk bond imploded then, the S\&Ls holding junk bonds went insolvent. The U.S. regulatory agencies then closed 1043 out of 3234 S\&Ls. 


\section{Wall Street Securitization \& Secrecy jurisdictions}

After 2000, Wall Street next moved into 'securitization' for financial products. But Wall Street's financial invention of the 'securitized mortgage' was really a fraudulent financial asset because (1) the rent had been stripped from the mortgage bonds and sold separately as a derivative and (2) the investment bank creators (e.g. Bear Sterns, Goldman Sachs, etc.) had not paid for the mortgages but only borrowed for them, with the long-term mortgages purchased by short-term loans. The investment banks went from banking integrity and fiscal due-diligence to fiscal casino banking: creating (1) a fraudulent capital asset and (2) borrowing-short-and lending-long to purchase mortgages. The mortgage bonds the investment banks held (and had not paid for) became the 'toxic assets' to the investment banks -which the government would have to buy from them in the bail-out, because the bonds could not be again sold (having no interest income).

Irving Minsky had specified the requirement that financial markets should trade real capital assets with rents and future liability. (Minsky, 1975) Had the then chair of the U.S. central bank appreciated Minsky's insights about the nature of a financial market, he should not have allowed Wall Street investment banks to sell the so-called 'securitized' mortgage-based-derivatives. Instead in 2000, the Chair of the U. S. Federal Reserve Bank had argued to the U.S. Congress that the derivative market should not be regulated. (Wolf, 2008)

The financial innovation event of 'securitization' is shown in Figure 7, along with a second event of 'secrecy jurisdictions'.

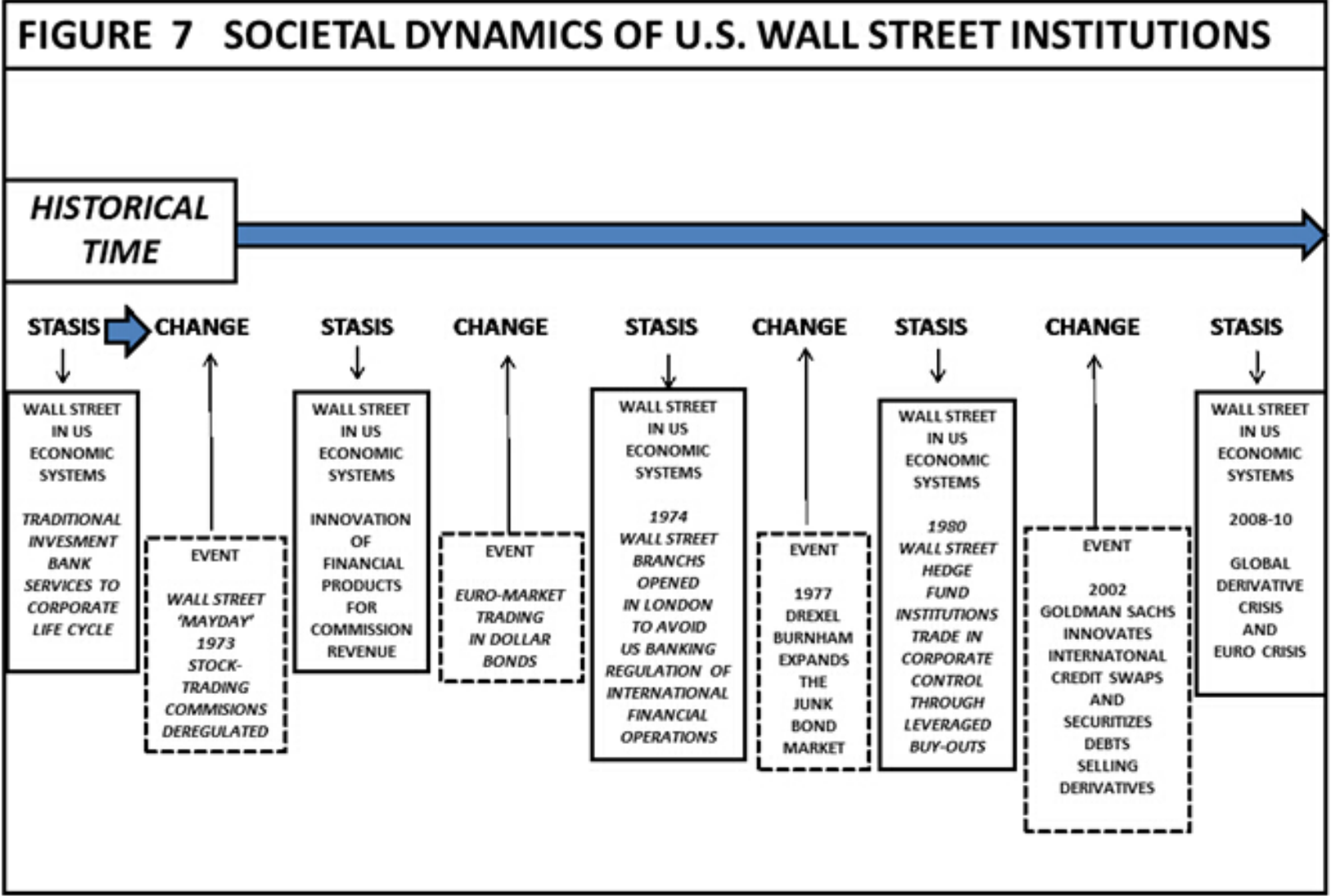

Figure 7. Change Events in the Evolution of Wall Street

In addition to the financial innovation of 'securitization', Wall Street also innovated ways to keep debt off of government books. This was a process which Nicholas Shaxson called 'secrecy jurisdictions' - making debt secret. (Shaxson, 2011) Wall Street created this product as a so-called 'credit swap'. Wall Street sold loans (disguised as currency credit-swaps) to municipalities in the US and in Europe, advertising low-interest rates in the short-term. The 'catch' was that the interest rates were tied to a currency exchange rate; and if the currency exchange rate changed the interest could jump higher.

For example, variable-interest-rate loans were sold to French cities, with the euro exchange rate coupled to the Swiss franc. Some of the financial results of 'credit-swaps' can be seen in the case of a small town in France, 
Châteauneuf-Les-Martigues. Noemie Bisserbe wrote: "The mayor of this sleepy town near the Mediterranean coast gathered a crowd in the community hall on a recent day to discuss complex instruments that most of them had never heard of: financial swaps. Over three hours, he described how a loan pegged to the Swiss franc that municipal officials took out years ago had become so burdensome that the southern French town could no longer afford to build the school it needed. Like several hundred cities across France, Chateauneur-les-Martigues took out a variable-interest-rate loan in the mid-2000s to restructure debt and reduce interest payments. The loans offered very low interest rates for the first few years, before the rate would start to vary according to the value of the Swiss franc." (Bisserbe, 2015)

The loans were made to cities with an initial low interest rate but coupled to the exchange rate of the Euro to the Swiss franc. These loans carried large commissions for the investment banks. Buyers bought them, assuming the risk was low based upon the integrity of municipalities. But in 2015, with the Euro crisis continuing in Greece, the value of the Euro dropped and that of the Swiss franc rose. Then the variable interest rates of the loans climbed. Noemie Bisserbe wrote: "Now, with the euro having sunk ... scores of municipalities across France have come to rue the day they accepted the offers. Interest rates on some loans started to increase during the financial crisis. That has accelerated in the six months since the Swiss National Bank abandoned a cap on the franc's value versus the euro.... The loan mess is turning into a municipal crisis for the French government . . . A handful of mayors have filed complaints against Dexia, claiming they weren't informed about the risks involved and seeking to cancel the loans. ... Chateauneur-les-Martigues says that, even if the government paid $60 \%$ of the fees to terminate its loan, the town still would need to pay 13 million euros in capital, interest and fees to get out of the 6.6 million euro loan it took out eight years ago." (Bisserbe, 2015)

This innovation by Wall Street investment banks to lure municipalities into variable-rate loans was obviously not in the long-term 'public good' of the cities. But after the Wall Street 'Mayday', investment banks around Wall Street no longer looked out for the public good interest of their clients - neither sellers nor buyers. Their goal was focused upon commissions on products, for which neither the seller nor buyer might really benefit.

Also suffering during this same period was Greece; and about Greece, Robert Reich wrote: "The Greek debt crisis offers another illustration of Wall Street's powers of persuasion and predation, although the Street is missing from most accounts. The crisis was exacerbated years ago by a deal with Goldman Sachs, engineered by Goldman's current CEO, Lloyd Blankfein. Blankfein and his Goldman team helped Greece hide the true extent of its debt, and in the process almost doubled it. . . In 2001, Greece was looking for ways to disguise its mounting financial troubles. The Maastricht Treaty required all eurozone member states to show improvement in their public finances, but Greece was heading in the wrong direction. Then Goldman Sachs came to the rescue, arranging a secret loan of 2.8 billion euros for Greece, disguised as an off-the-books "cross-currency swap"- a complicated transaction in which Greece's foreign-currency debt was converted into a domestic-currency obligation using a fictitious market exchange rate." (Reich, 2015) At the time, Blankfein was head of the department selling cross-currency swaps, and later he was promoted to the CEO of Goldman Sachs.

The 'cross-currency swap' was really a loan to Greece disguised as an exchange into Euros of other currencies. Robert Reich wrote: "As a result, about 2 percent of Greece's debt magically disappeared from its national accounts. . . For its services, Goldman received a whopping 600 million euros ( $\$ 793$ million). That came to about 12 percent of Goldman's revenue from its giant trading and principal-investments unit in 2001—which posted record sales that year. The unit was run by Blankfein." (Reich, 2015)

It was in 2006 when Lloyd Blankfein became CEO of Goldman Sachs, after the previous head of Goldman Sachs, Henry Paulson, was nominated for U.S. Secretary of Treasury. (As Treasury Secretary, Paulson proposed to Congress the Emergency Economic Stabilization Act of 2008, which authorized him to spend up to $\$ 700$ billion to buy the 'toxic assets' of Wall Street. These 'toxic assets were the mortgage-based (securitized) derivatives, which Wall Street investment banks had sold world-wide and which triggered the Global Financial crisis of 2008.) While derivatives were being manufactured by Goldman Sachs and others, Blankfein in 2006 received \$54.4 million dollars as salary and bonus from Goldman Sachs. In 2007, Blankfein earned again $\$ 54$ million dollars. But in 2014, he received only \$24 million, since profits in Goldman Sachs had declined after the 2008 Wall Street debacle.

In 2010, U.S. Senate investigations about the 2008 Wall Street financial crisis, Lloyd Blankfein was called to testify. James Quinn reported: "Lloyd Blankfein has admitted that he believes Goldman Sachs has no moral obligation to tell clients it is betting against a product it is asking them to buy. The stark admission - made by the bank's chairman at the end of a more than nine-hour marathon hearing before the US Senate - came in spite of his assertion that 'I think people trust us' as he tried to fend off accusations that Goldman inflated the US housing bubble. Senator Carl Levin 
told the veteran banker that he wouldn't trust Goldman. Levin repeatedly asked whether the bank would disclose its position: 'When they're buying something you solicit them to buy, and then you're taking a position against them?' Mr. Blankfein responded: 'I don't believe there is any obligation' to tell investors. I don't think we'd have to tell them, I don't think we'd even know ourselves." " (Quinn, 2010)

Traditionally an important aspect of banking is its 'public good' in ensuring that financial transactions are honest, sound, and transparent - banking integrity. But in 2010, the head of Goldman Sachs (then the most successful international investment bank in the world) did not believe in the integrity of his firm (and even doubted it could distinguish integrity, when he said: 'I don't think we'd even know ourselves.') This rejection of banking' integrity' for its clients astounded Senator Levin. James Quinn reported: "His (Blankfein's) responses are key in the light of the Securities and Exchange Commission's civil fraud charges against Goldman Sachs in connection with a \$1bn mortgage-backed derivative which the regulator alleges was mis-sold to investors, allowing one investor to benefit over another." (Quinn, 2010)

In addition to Goldman Sachs, other Wall Street institutions in the financial grid were eager to also engage in unethical financial operations in 'off-market' transactions both in the fraudulent 'derivatives' and in the 'credit swaps'. Robert Reich wrote: "Until 2008, European Union accounting rules allowed member nations to manage their debt with so-called off-market rates in swaps, pushed by Goldman and other Wall Street banks. In the late 1990s, JPMorgan enabled Italy to hide its debt by swapping currency at a favorable exchange rate, thereby committing Italy to future payments that didn't appear on its national accounts as future liabilities. But Greece was in the worst shape, and Goldman was the biggest enabler. Undoubtedly, Greece suffers from years of corruption and tax avoidance by its wealthy. But Goldman wasn't an innocent bystander: It padded its profits by leveraging Greece to the hilt-along with much of the rest of the global economy. Other Wall Street banks did the same. When the bubble burst, all that leveraging pulled the world economy to its knees." (Reich, 2015)

An interesting term, this 'off market'! Economically, financial markets are supposed to be open and transparent in order for the optimal prices to be set in equilibrium of supply-and-demand. Why then would financial market makers, such as Goldman Sachs and JPMorgan want to distort the sovereign bond market by hiding bond-like transactions in 'off-market credit swaps'? Let us call these 'off-market credit swaps' a financial innovation of 'secrecy jurisdictions', whose purpose was to make secret and hide government debt profligacy from the international bond markets.

Goldman Sachs had a good thing going for their executives. Investment banks could innovate, such as (1) hide government debt in a 'secrecy jurisdiction' until the sovereign bond market bursts and (2) 'securitize' mortgage debt until the mortgage market bursts. In all cases of financial catastrophes, bankers appeared to believe that the governments of America and Europe would bail out 'banks-too-big-to-fail'. Since none of the investment bankers involved in the financial innovations of the decade of 2000s went to jail, the governments involved judged that all the innovations in the international financial grid of 'light regulation' were legal. The governments, by letting their banks bring down the financial system and then bailing them out, signaled that all was legal, only unfortunate.

But were they ethical? Robert Reich judged: "Goldman Sachs and the other giant Wall Street banks are masterful at selling complex deals by exaggerating their benefits and minimizing their costs and risks. That's how they earn giant fees. When a client gets into trouble - whether that client is an American homeowner, a US city, or Greece - Goldman ducks and hides behind legal formalities and shareholder interests. Borrowers that get into trouble are rarely blameless, of course. They spent too much and were gullible or stupid enough to buy Goldman's pitches. Greece brought on its own problems, as did many American homeowners and municipalities. But in all of these cases, Goldman knew very well what it was doing. It knew more about the real risks and costs of the deals it proposed than those who accepted them. 'It is an issue of morality,' said the shareholder at the Goldman meeting where Oakland came up. Exactly.” (Reich, 2015)

As intermediaries creating their financial products, investment banks in the twenty-first century were less interested in banking ethics and more interested in banking commissions.

\section{History - Offshore Banking Grid}

We have constructed a model of the international financial grid focused upon the production of financial products (for financial markets) by investment banks; and also we have reviewed some of the sellers of capital assets for such products (e.g. corporate raiders); but what about the buyer side. Who are the 'buyers' of the innovative financial products? 
Who would buy a 'junk bond'? They are highly risky, depending upon the ability of the captured corporation to pay off its leveraged junk-bond debt. Who would want companies to be loaded with debt until they were uncompetitive?

Who would buy a 'securitized product'? A securitized product pays only the interest from a capital asset, without the risk-reducing collateral of the 'principle' of the asset. Accordingly if the interest failed to be paid, there is no collateral to back the loan.

Who would by a currency-exchange swap? Who would want to help countries and cities hide their debt? And who would believe in a 'credit default swap' as a real insurance contract?

The answer to these questions is probably: 'no one'. Certainly no bank (or financial institution) which was committed to exercising 'due diligence' (finding out whether or not the loan is a good risk). So why would some banks buy the products, not exercising due diligence? The answer is that some banks did buy the products, disregarding due diligence; and many of these were banks in the so-called 'off-shore' banking industry.

An investigative financial reporter, Joanne Ramos, pointed to offshore banks as critical elements of the modern international financial grid. Ramos, wrote: "In a globalized economy, money moves instantly and anonymously across borders. This can benefit terrorists, drug traffickers and rogue nations in need of cash. Keeping such customers out of the world's sprawling financial system is becoming ever harder. Financial regulators have another big concern. Footloose capital transmits not just tainted money but financial crises too. The huge growth in the use of esoteric derivatives and the rise of hedge funds have made it increasingly difficult to understand where financial risk lies, partly because much of it is hidden away on islands with variable supervision. Offshore holdings now run to $\$ 5$ trillion-7 trillion, five times as much as two decades ago, and make up perhaps 6-8\% of worldwide wealth under management, according to Jeffrey Owens, head of fiscal affairs at the OECD. Cayman, a trio of islands in the Caribbean, is the world's fifth-largest banking centre, with $\$ 1.4$ trillion in assets. The British Virgin Islands (BVI) are home to almost 700,000 offshore companies." (Ramos, 2007)

The offshore banking industry has turned out to be a critical institutional sector of the international financial grid, having the volume to buy in large amounts the questionable financial innovations sold by the investment banking industry. Off-shore banks buying these questionable investments were not performing 'due diligence' in financial trading. This was because off-shore banks had no means of investing the huge amounts of the international cash flow going into their deposits -- except through international investment banks. As noted, from 6 to $8 \%$ of the world's wealth flowed into the offshore banking industry.

Other investigative reporters have also examined the off-shore industry. Nicholas Shaxson also emphasized the importance of the institutional role of off-shore banks: "Towering inequalities in Europe and the United States, not to mention in underdeveloped countries, cannot be understood properly without exploring the role of secrecy jurisdictions. The systematic looting of the former Soviet Union, and the merging of the nuclear-armed country's intelligence apparatus with organized crime, is substantially a story that unfolds in London and its offshore satellites. The political strength of Saddam Hussein had important offshore underpinnings, as does the power of North Korea's Kim Jong-Il today. Prime Minister Silvio Berlusconi's strange hold over Italian politics is significantly an offshore story. The Elf affair, discussed earlier, which helped powerful French elites float above and out of reach of French democracy, had secrecy jurisdictions at its heart ... The narcotics industry alone generates some $\$ 500$ billion in annual sales worldwide. To put this into perspective, that is twice the value of Saudi Arabia's oil exports. The profits made by those at the top of the trade find their way into the banking system, the asset markets, and the political process through offshore facilities. You can only fit about $\$ 1$ million cash into a briefcase. Without offshore, the illegal drugs trade would be more like a cottage industry." (Shaxson, 2011)

The offshore banks (outside proper bank regulatory authority) make money by helping people and corporations to hide money from taxes and also to launder money gained from illegal or corrupt activities. The off-shore banking institutions include locally licensed banks and financial institutions. What happens to all these deposits (e.g. \$1.4 trillion in the Cayman Islands), since the offshore banks and institutions have no financial investments in which to put all that savings. They invest (buy) products sold by the investment banks with branches in the City of London. Nicholas Shaxson wrote: "London's first claim to be a tax haven is . . . its role as the creator and developer of the Euromarkets -- Wall Street's giant escape route from the checks and balances of U.S. financial regulation. Here the subsidiaries and affiliates of U.S. commercial banks have long been allowed to engage in, among many other things, investment banking, "casino banking," as some have called it - something the Glass-Steagall Act of 1933 explicitly prohibited. Over the years, as this business became more integral to their global banking models, Wall Street could increasingly pressure the U.S. government to do away with the original restrictions to allow them to do at home what 
they already did offshore, and this was arguably the main factor that led to the repeal of Glass-Steagall in 1999." (Shaxson, 2015)

Here is the connection between Wall Street's 'Mayday' (the end of regulated commissions) and Wall Street's search for deregulation. In the London-based Eurodollar market, Wall Street institutions went to London to engage in selling unregulated international financial products. The London branches of Wall Street investment banks have been central to the sale of the products which blew up Wall Street in 2008. Nicholas Shaxson wrote: "London provides endless loopholes for U.S. financial corporations, and many U.S. banking catastrophes can be traced substantially to those companies' London offices. The unit that blew up the insurance company American International Group (AIG), putting the U.S. taxpayer on the hook for $\$ 182.5$ billion, was its four hundred- strong AIG Financial Products unit, based in London. The court-appointed examiner looking into the collapse of Lehman Brothers in September 2008 found it had used a trick called Repo 105 to shift $\$ 50$ billion in assets off its balance sheet, and that while no U.S. law firm would sign off on the transactions, a major law firm in London was delighted to oblige, without breaking the rules. . . A A little-noticed IMF paper in July 2010 estimated that by 2007 the seven largest players in the marketLehman Brothers, Bear Stearns, Morgan Stanley, Goldman Sachs, Merrill/ BoA, Citigroup, and JPMorgan - had shifted $\$ 4.5$ trillion off their balance sheets in this way. (Shaxson, 2015)

To understand the 'buy-side' of the international financial grid, one must analyze the 'off-shore banking industry', as depicted in Figure 8. One needs two topological planes: one to diagram the system of financial transactions in the grid and a second to diagram the institutional connections of off-shore banks to the centralized international investment banking system. These two planes are (1) the disequilibrium financial systems plane and (2) the institutions of the off-shore banking network which connect to an international financial center. The offshore banking network operates by: (a) collecting savings deposits from individuals \& corporations seeking financial secrecy, (b) setting up an institutional account with an investment bank in the City of London financial center, and (c) purchasing financial products from the investment banks in London.

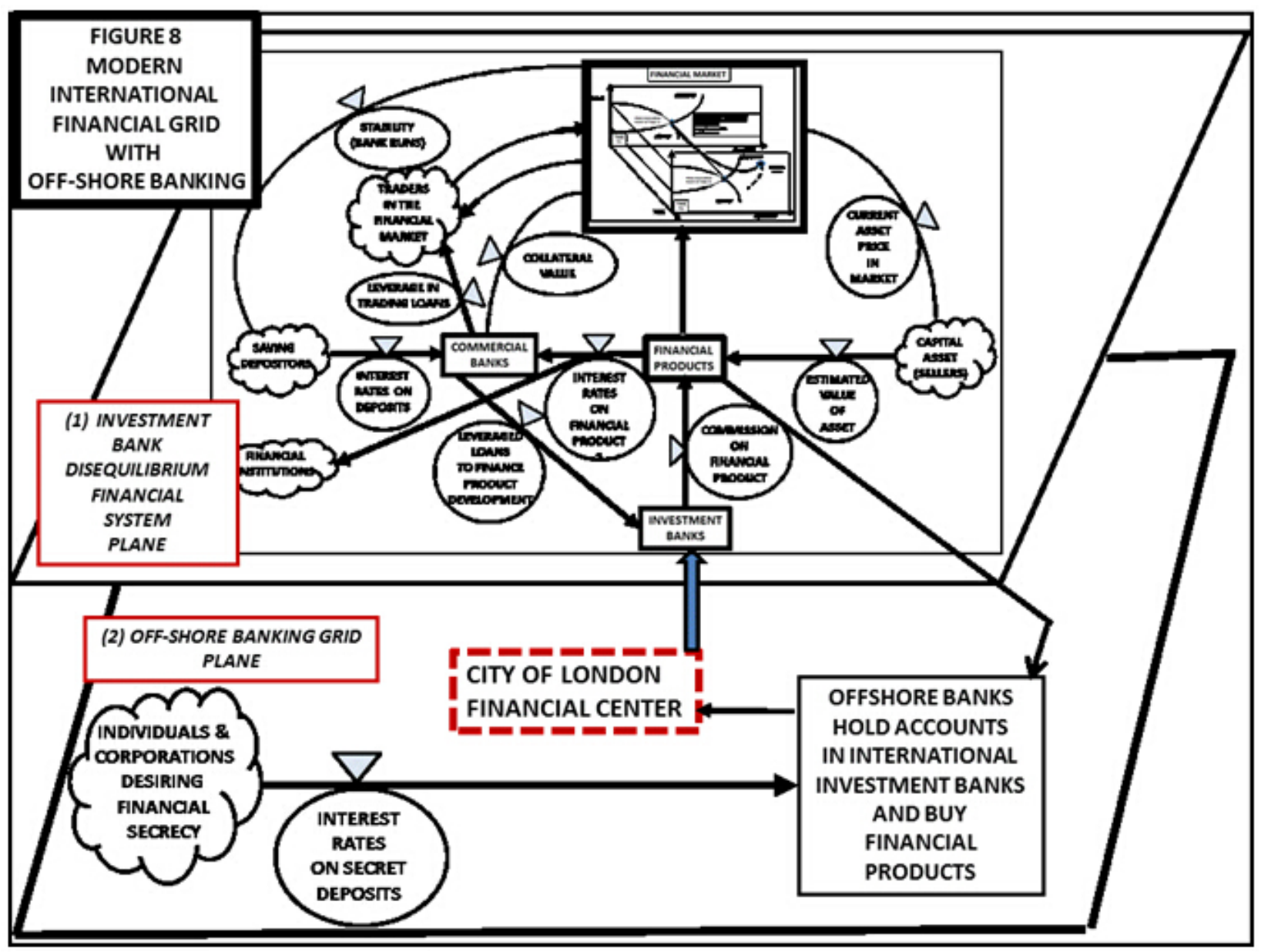

Figure 8. Modern International Financial Grid with Off-Shore Banking 
Two topological planes are necessary because there are two different networks in the financial grid: (1) investment bank network and ((2) off-shore banking network. These two networks are connected through the City of London Financial Center. This model shows that the offshore-bank network is financially effective because it ties into a central location, the City of London Financial Center. The City of London does not regulate the international investment banks dealings with the offshore network - as sellers (investment banks) and buyers (offshore banks) -of financial innovations which may or may not have any public good. And the model emphasizes that some of the international buyers of the investment banks 'financial innovations' were the off-shore banks which needed high-interest income to pay interest to their secret clients -- individuals and corporations depositing in the off-shore banks. These off-shore banks do not care about the soundness of the financial products', just as long as the investment banks assure them that they are low-risk and bear high interest.

How does the City of London act as a center for the off-shore banking network? Nicholas Shaxson wrote: "The next component of the City's offshore status is its role in running, protecting, and being fed by Britain's offshore spider web. This web of partly British tax havens around the world provides the City with three things. First, it captures passing foreign business and assets nearby and channels them, and the business of handling them, to London, just as a spider web catches insects. Second, it is a storage mechanism for assets. Third, it is a kind of money-laundering filter that lets the City get involved in foreign dirty business but at sufficient distance to minimize the stink." (Shaxson, 2015)

The historical impact of the Bank of England allowing the Midland Bank to engage in foreign exchanges was to begin the deregulation of banks located in the City of London. Later in 1986, London financial deregulation was enacted formally by the Margaret Thatcher's government. The London Stock Market would no longer charge fixed trading commissions and investment banks could act for both buyers and sellers in the trading. Nigel Lawson wrote: The radical reform of the London Stock Exchange came to be known as 'Big Bang' . . Without that reform, it is doubtful if London would have retained its place as Europe's pre-eminent financial centre, and certain that it would not have become the foremost truly international financial centre of the modern globalized economy that it is today, to the great benefit of the British economy as a whole. . in 1979, the Office of Fair Trading decided to launch an investigation into the restrictive practices of the London Stock Exchange, in particular the system of fixed minimum commissions. ... The problem, as I (Lawson) saw it, was not merely the restrictive practices themselves: in addition to fixed minimum commissions, these included the 'single capacity' rule, which enforced a separation between brokers acting as agents for their clients on commission and jobbers who made the markets and theoretically provided liquidity by holding lines of stocks and shares on their books; the requirement that both brokers and jobbers should be independent and not part of any wider financial group; and the exclusion of all foreigners from stock exchange membership." (Lawson, 2003)

Thus a London 'Mayday' occurred in the 'Big Bang' in London, which then deregulated fixed commissions on stock trades in Britain, forcing British investment banks to financially 'innovate' (just like the U.S. Wall Street). Nicholas Shaxson wrote: "By the early 1980s the main elements of the modern offshore system were in place and growing explosively. An older cluster of European havens, nurtured by old European aristocracies and led by Switzerland, was now being outpaced by a new network of more flexible, aggressive havens in the former outposts of the British Empire, themselves linked intimately to the City of London. A state within the British state, the City had been transformed from an old gentleman's club operating the financial machinery of empire, steeped in elaborate rituals and governed by unspoken rules about what "isn't done," into a new, brasher, deregulated global financial center dominated by American banks and linked intimately to this new British spider web." (Shaxson, 2015)

\section{Public Good (or Bad) in the Financial Grid}

As we previously noted, there is a long-standing and wide-spread debate in economics about the good or harm of international capital flows for national economic development. Barry Eichengreen wrote: "The normal presumption in economics is that markets know better than governments and that, left to their own devices, they allocate resources reasonably well. Yet the suspicion remains that there is something different about international financial markets. The founding fathers of the Bretton Woods System, Harry Dexter White and John Maynard Keynes, certainly thought so. The Bretton Woods Agreement negotiated under their guidance, although encouraging economic liberalization generally, authorized (indeed, encouraged) countries to retain restrictions on international financial transactions." (Eichengreen, 2004)

One of the 'public good' aspects believed to be about international capital flows is that the flows direct capital into a developing country (in order to finance development). Eichengreen wrote: "International financial transactions transfer resources from high-saving to low-saving countries." (Eichengreen, 2004) 
This is how the contemporary financial grid should work, but does it? And this is why the empirical reality of institutional practices (micro-economics) should be investigated in particular historical contexts. Does general economic theory really work in a particular time and place of history? Now the empirical evidence is that in the present historical context of the early twenty-first century is that there is harm being done in the modern international financial grid.

The non-profit organization of Global Financial Integrity examined 'harm' by measuring the net flows of capital from and into developing countries. This net-flow is important because one economic need of poor countries is capital for development. If there is a net flow of capital out of a developing country, then wealth needed for economic development is being lost to the future of the country. The surprising findings of Global Financial Integrity is that the international financial grid has been sending capital not 'into' but 'out of' developing countries - a negative capital flow. Dev Kar and Joseph Spanjers wrote: "This report, the latest in a series of annual reports by Global Financial Integrity (GFI), provides estimates of the illicit flow of money out of the developing world-as a whole, by region, and by individual country-from 2003-2012, the most recent ten years of data availability. The study finds that between 2003 and 2012, the developing world lost US \$6.6 trillion in illicit outflows. In real terms, these flows increased at 9.4 percent per annum. After a brief slowdown during the financial crisis, illicit outflows are once again on the rise, hitting a new peak of US $\$ 991.2$ billion in 2012." (Kar and Spanjers, 2014)

The negative flow is continuing and significant. Kar and Spanjers wrote: "To put this in perspective, the cumulative total of official development assistance (ODA) to the developing countries in this report from 2003 to 2012 was just US $\$ 809$ billion. In 2012, the last year in this study, ODA to these countries stood at US $\$ 89.7$ billion, according to OECD data sourced from the World Bank. That means that for every single one of those US $\$ 89.7$ billion in development aid that entered these developing countries in 2012, over US \$10 in illicit financial flows (IFFs) came out. ... GFI measures illicit financial outflows using two sources: (1) outflows due to deliberate trade mis-invoicing (GER) and (2) outflows due to leakages in the balance of payments, also known as illicit hot money narrow outflows (HMN). The vast majority of illicit financial flows, $77.8 \%$ in the 10 -year period covered in this report, are due to trade mis-invoicing." (Kar and Spanjers. 2014)

'Mis-invoicing' is a deliberate attempt to make secret the real nature of the financial transaction. The reasons for 'mis-invoicing' (hiding the nature of the transaction) are to (1) avoid national exchange restrictions, (2) reduce taxes, and (3) hide government corruption. Kar and Spanjers wrote: "Potential drivers of trade mis-invoicing can be related to regulatory, fiscal, and governance issues although their relative importance can vary from one country to another. . . . In 2013, there were 113 countries that maintained exchange restrictions. Such practices give rise to differences in exchange rates between different exchange markets or among approved official transactions. There is a tendency for black markets in foreign exchange to develop as private economic agents seek to profit from the differences in exchange rates. ... Fiscal issues can also drive trade mis-invoicing. While importers may initially pay more by over-invoicing imports, they will continue to do so as long as the reduction of corporate profits (due to larger import costs) outweighs the increased import duties payable, which allows the company to pay a lower corporate profits tax. . . Finally, governance issues and corruption in particular tend to be a major driver of illicit flows. Le and Rishi find that there is a significant link between corruption and capital flight, based on the World Bank Residual method adjusted for trade mis-invoicing. "(Kar and Spanjers, 2014)

In Nicholas Shaxson's study of oil corruption in Angola, he was impressed with the scale of the corruption: "My personal belief, based on years of investigating Angola's economy . . . is that official estimates (equivalent to just over 9 percent of its $\$ 51$ billion in oil and diamond exports during that time) simply have to be a gross underestimate of the losses. Many billions have disappeared offshore through opaque oil-backed loans channeled outside normal state budgets, many of them routed through two special trusts operating out of London." (Shaxson, 2015)

The impact of the offshore banking sector of the financial grid has been particularly great for crime (money laundering), as well as for corruption (flows of petro-dollars from 'less-developed countries' dictators). For example in 2004, Lucy Komisar wrote: "A detailed analysis of Saddam Hussein's secret money-laundering techniques shows here for the first time how he used the same offshore money launderers as Osama bin Laden. That covert money network, based in the tax havens of Switzerland, Liechtenstein, Panama and Nassau, helped bankroll the war machines of both Iraq and al-Qaida." (Kosmisar, 2004)

The existence of a banking network (devoted to secrecy) networked into a banking network (devoted to transparency) provide the institutional framework for economic abuses of the financial grid - assisting tax-avoidance, criminal activity, governmental corruption, and financial fraud. 


\section{Results -- Macro-Economic Models and Micro-Economic Institutional Analysis}

In mathematical framework of topology, we have constructed a price-disequilibrium model of a financial market embedded within a systems dynamics model of intermediary financial institutions (in order to connect financial product supply to demand). This provides a model of the transaction processes in international capital flows -- a macro-economic model of an international financial grid. Moreover this methodological use of a systems dynamics macro-economic model provides a graphic structure in which to embed the empirical reality of the micro-economic institutional procedures of financial institutions -- operating in a specific historical context. The macro-economic model can express general economic theory, while the micro-economic institutional context can express historical reality. How is the grid connected? How does a historical grid really work? What kinds of financial products and innovations flow through the grid? What public benefit do these products give (if any)?

What is particularly interesting in this model is that two kinds of networks are connected through a centralized feature. The networks of off-shore banks and international investment banks are interconnected by banking located in London -- creating a grid wherein vast sums of capital can flow in an unregulated and surprising manner. Nicholas Shaxson described the importance of the connection between the two networks: "Financial deregulation and globalization? Offshore is the heart of the matter. The rise of private equity and hedge funds? Offshore. Enron? Parmalat? Long Term Capital Management? Lehman Brothers? AIG? Offshore. Multinational corporations could never have grown so vast and powerful without the tax havens. Goldman Sachs is very, very much a creature of offshore. And every significant financial crisis in the world since the 1970s, including the latest global economic crisis, is very much an offshore story. The decline of manufacturing industries in many advanced countries has many causes, but offshore is a big part of the story. Tax havens have been central to the growth of debt in our economies since the 1970s. The growth of complex monopolies in certain markets, or insider trading rings, or gigantic frauds, almost always involves secrecy jurisdictions as major or central elements. This is not to say that all of these problems don't have other explanations too. They always do. Tax havens are never the only story because offshore exists only in relation to elsewhere. That is why it is called offshore. Without understanding offshore, we will never properly understand the history of the modern world." (Shaxson, 2015)

The unregulated off-shore banking sector operates not upon 'transparency' of financial transactions but upon 'secrecy'. Secret transactions connect buyers (wishing tax avoidance or money laundering) to deposits in off-shore banks which then connect to financial products of investment banks, through unregulated banking in the City of London financial center. The secrecy in the connected networks has created conditions of financial abuse.

An example of structure-to-function relations (and about the function of secrecy in the structure of the connected networks) can be seen in events related to government regulation. After the financial debacle of unregulated derivatives trading and of proprietary trading by integrated banks, Lucy Komisar wrote: "As I write this (in July 2010), the U.S. Senate is debating a major financial reform bill in which the credit default swap, a kind of (insurance for) derivatives, plays a significant part. An amendment to that bill, proposed by Senators Carl Levin (D-MI) and Jeff Merkley (D-OR), would ban banks from proprietary trading. There are a lot of high-rolling bankers who do not want that amendment to pass, because it will mess up their plans to repatriate foreign profits into the United States, untaxed, by trading in derivatives on their own accounts. The clearinghouse ICE Trust U.S. forms a central part of these plans. What is ICE Trust U.S., and who owns it? ICE US Holding Co., which was established in 2008 as the parent of ICE Trust U.S., is located in the Cayman Islands. Yet none of the owners of ICE US Holding Co. are based in the Caymans. Among the owners of the Cayman's company are Citigroup, Goldman Sachs, J.P. Morgan, Merrill Lynch and Morgan Stanley, which are headquartered in New York. Bank of America, which now owns Merrill Lynch, is based in Charlotte, North Carolina. (Komisar, 2010)

Thus of the 700,000 companies in the British Virgin Islands and Cayman Islands, there was at least one 'blind' company for Wall Street banks -- Citigroup, Goldman Sachs, J.P. Morgan, Merrill Lynch, Morgan Stanley, and Bank of America. Why were they hiding? Their business was to provide 'secrecy jurisdictions'; and to do secret business, you must be secret. The modern offshore system operations were making finances secret. Secret financial transactions turned out to provide a big market for international investment banks.

Nicholas Shaxson summarized the negative impact of a regulated financial grid coupled to an unregulated financial network: "The secrecy jurisdictions, by applying a sort of super-lubricant to the flow of capital around the world, dramatically widen these chasms inside capitalism. They are the supreme generators of remoteness and artificiality: creating secrecy barriers and generating unfathomable complexity as corporations garland their financial affairs around the world's tax havens to fox the world's tax authorities and regulators, and to shield particular investors against other nations' laws and regulations. As we have discovered since 2007, the system was wildly inefficient: 
consider the wealth destroyed and the costs heaped onto the shoulders of taxpayers. Capital no longer flows simply to where it gets the best return but to where it can secure the best tax subsidies, the deepest secrecy, and to where it can most effectively evade the laws, rules, and regulations it does not like. None of this has anything to do with allocating capital more efficiently. Keynes would have viewed the explosion in offshore finance since the 1970sand the massive capital flight it fostered - with horror." (Shaxson, 2015)

Now if this off-shore banking network (centralized in the City of London) remains unregulated and of questionable ethics, why would established banks use such a system? Joseph Stiglitz is a Nobel laureate for economics and former World Bank Chief Economist; and in 2010, he said to the reporter Lucy Komisar: "You ask why, if there's an important role for a regulated banking system, do you allow a non-regulated banking system to continue? It's in the interest of some of the moneyed interests to allow this to occur. It's not an accident; it could have been shut down at any time. If you said the US, the UK, the major G7 banks will not deal with offshore bank centers that don't comply with G7 banks regulations, these banks could not exist. They only exist because they engage in transactions with standard banks."(Komisar, 2010) The secrecy of the financial grid is protected by banking interests who generate a lot of wealth for their own private good and who lobby government institutions not to regulate (or regulate with only a 'light touch') the processes in the financial grid.

\section{Summary}

A systems dynamics disequilibrium-pricing model of a financial grid provides the structural framework (macro-economic) for a functional analysis of actual institutional procedures (micro-economics). As shown in Figure 9, one can add into the disequilibrium systems model of the international financial grid a third plane of networks (3) into which the planes of investment bank processes (1) and the planes of the off-shore bank processes (2) all connect. This emphasizes the importance of a network structure in the financial grid, as operated with information-communication technologies.

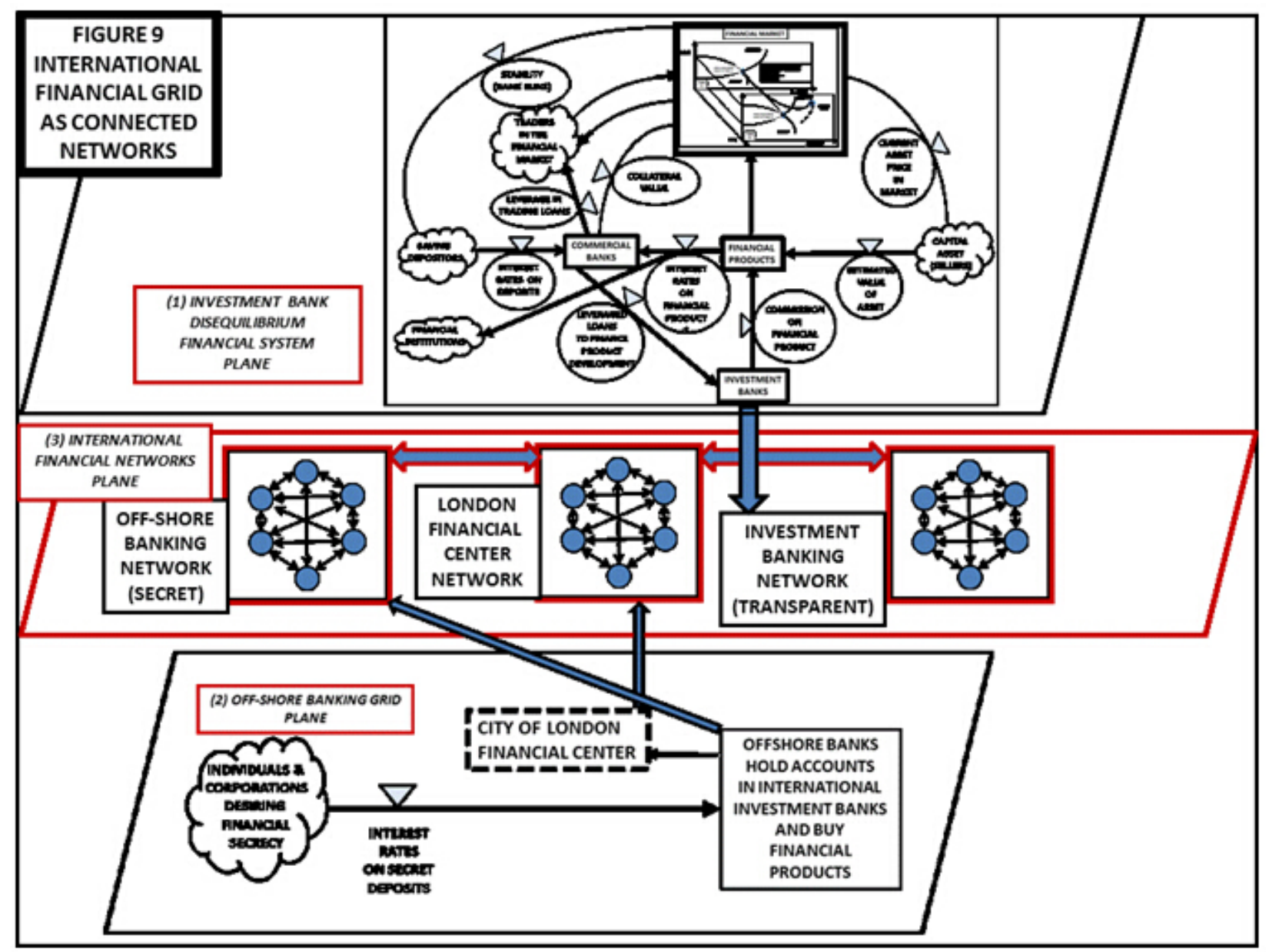

Figure 9. Three Networks Connecting Together as the International Financial Grid 
Plane 3 of the grid expands to the product processes in Plane 2 of investments and also to Plane 2 in the deposit processes of the offshore banks. This networked disequilibrium-systems-model of the modern financial grid depicts four particular features.

1. The grid partitions into a legitimate regulated network (investment banks) and an illegitimate unregulated network (off-shore banking);

2. The illegitimate unregulated network of off-shore banking serves purposes of tax-avoidance, laundering of government financial corruption, and illegal criminal finances;

2. The two networks (regulated and unregulated) connect through an 'unregulated international financial center' in the City of London - connecting the investment bank products between legitimate and/or illegitimate sellers and buyers;

3. Because of the lack of international regulation in the international grid, investment bank products may serve private good but may not always serve the public good; while the unregulated network economically serves private good but seldom public good;

4. The circulation in the whole network of private-good products can create instability through Minsky financial bubbles in the financial markets of the financial innovations by the international investment banks.

5. Without the (presently unregulated) cooperation between investment banks (in national regulated domains) with commercial banks (in offshore unregulated domains), the abuse of capital flows could not occur at the recurrent events of quick and large-scale global financial crises. The off-shore banking network presently provides the large volume of capital necessary to move all the imprudent financial products created by international investment banks.

Through modeling the processes of the international finance institutions as an international capital-flow grid, one can pinpoint where and how the practices of the institutions (micro-economics) affect the public good and the stability of international financial system (macro-economics). In this case of financial markets, it is important to use the methodology of disequilibrium systems as a macro-economic format, into which one can place the empirical micro-economics of actual institutional procedures. The 'empiricism' of the macro-model occurs as to how exactly 'real institutional procedures' control the 'real flows' of capital - for the private good of a financial system, and hopefully for the public good rather than harm.

\section{Limits of Research and Implications for Future Research}

The limits of this research is that it is primarily a structural framework; and for a fully developed model, one needs to add quantitative data about the flows in the system. It is presently difficult to get information on the quantity of flows in the model. Future research could focus (1) upon measurement of quantitative flows in the system arrows and (2) developing quantitative algorithms for the amount of control a valve has upon flow.

\section{References}

Arnade, Chris. (2015). "Blame the Banks'." The Atlantic. July 16.http://www.theatlantic.com/business/archive/2015/07/greece-crisis-banks-greedy/398603/

Betz, Frederick. (2011). Societal Dynamics (New York, Springer) ISBN 978-1-4614-1278-6

Betz, Frederick. "Disequilibrium Pricing Theory." (2014). Theoretical Economics Letters. Scirp.org. February. Vol.4 No.1 2014 [ID: 1500464] (http://www.scirp.org/journal/tel)

Bisserbe, Noemie. (2015). "Toxic Loans Wallop French Towns." Wall Street Journal. July 20.http://www.wsj.com/articles/toxic-loans-wallop-french-towns-1437411450

Bruck, Connie. (1988). The Predators' Ball. Simon and Schuster. Published with a new chapter by Penguin Books. 1989.

Eichengreen, Barry. (2004). Capital Flows and Crises. MIT Press.

Fisher, Irving. (1933). "The Debt-Deflation Theory of the Great Depression." Econometrica, October 1933. http://dx.doi.org/10.2307/1907327

Kar, Dev \& Joseph Spanjers. (2014). Illicit Financial Flows from Developing Countries: 2003-2012. Global Financial Integrity. December. http://www.gfintegrity.org/wp-content/uploads/2014/12/Illicit-Financial-Flows-from-Developing-Countries-200 3-2012.pdf 
Komisar, Lucy. (2010). "The Wall Street ICEcapade.” The Komisar Scoop. May 18. The American Interest, July-Aug 2010 (online May 18, 2010) http://www.thekomisarscoop.com/tag/credit-default-swaps/

Komisar, Lucy. (2004). "Saddam's secret money laundering trail." United Press International (UPI), June 2, 2004. The Komisar Scoop. http://www.thekomisarscoop.com/2004/06/saddam\%E2\%80\%99s-secret-money-laundering-trail/

Lawson, Nigel. (2006). Big Bang 20 years on -- New challenges facing the financial services sector. (Collected Essays with a Foreword by Nigel Lawson). Centre For Policy Studies. 57 Tufton Street, London SW1P 3QL.

Mcgee, Suzanne. (2010). Chasing Goldman Sachs: How the Masters of the Universe Melted Wall Street Down...And Why They'll Take Us to the Brink Again. Crown Publishing Group.

Minsky, Hyman. (1975). John Maynard Keynes. Columbia University Press (reprinted in 2008 by Mc Graw Hill)

McCulley, $\quad$ Paul. $2007 . \quad$ Remarks". http://web.archive.org/web/20091124124300/http://www.pimco.com/LeftNav/Featured+Market+Commentary/F F/2007/GCBF+August-+September+2007.htm

Roumeliotis, Greg. (2014). "KKR doubles down on First Data, leading \$3.5 billion investment." Reuters. June 19. http://www.reuters.com/article/2014/06/19/firstdata-kkr-idUSL6N0P03AL20140619

Reich, Robert B. (2015). "How Goldman Sachs Profited From the Greek Debt Crisis." August 3-10. The Nation. http://www.thenation.com/article/goldmans-greek-gambit/

Ramos, Joanne. (2007). "Places in the sun: Offshore Financial Centres." The Economist. February 22. http://www.economist.com/node/8695139

Quinn, James. (2010). "Goldman boss Lloyd Blankfein denies moral obligation towards clients." The Telegraph. April http://www.telegraph.co.uk/finance/newsbysector/banksandfinance/7642325/Goldman-boss-Lloyd-Blankfein-de nies-moral-obligation-towards-clients.html

Sender, Henny. (2014). "KKR seeks to make the numbers work at First Data." Financial Times. September 18. http://www.ft.com/intl/cms/s/0/3adee562-3d30-11e4-a2ab-00144feabdc0.html?siteedition=intl\#axzz3RXONojG 6

Shaxson, Nicholas (2011). Treasure Islands: Uncovering the Damage of Offshore Banking and Tax Havens. St. Martin's Press. Palgrave McMillan.

Wolf, Martin. (2008). "Why Greenspan does not bear most of the blame", Financial Times, April 8.

Wolf, Martin. (2014). The Shifts and the Shocks: What we've learned - and have still to learn - from the financial crisis. Penguin Books Ltd. 